\title{
The Effect of DER, PER and EPS on the Share Price of Food and Beverage Companies on the Indonesia Stock Exchange
}

\author{
Dian Indah Sari ${ }^{1 *}$, Slamet Maryoso ${ }^{2}$ \\ 1,2 Universitas Bina Sarana Informatika, Jakarta, Indonesia \\ *Corresponding Author. Email : dianindahsari1977@gmail.com
}

\begin{abstract}
This study aims to analyze the effect of DER, PER and EPS on share prices of food and beverage companies in the Indonesia Stock Exchange. This research is quantitative descriptive. The data collection method is literature study. This study took samples from food and beverage industry companies listed on the Indonesia Stock Exchange for the period 2016-2019. Multiple Linear Regression analysis test and Classical Assumption test were used for data analysis techniques. The conclusions of this study are as follows: first, the variable (DER) has no significant and positive effect on share prices of food and beverage industry companies. Second, the variable (PER) has a significant and positive effect on share prices of food and beverage industry companies. Third, the variable (EPS) has a significant and positive effect on share prices of food and beverage industry companies. Fourth, the variables (DR), (PER) and (EPS) simultaneously have a significant and positive effect on the share prices of food and beverage industry companies listed on the Indonesia Stock Exchange for the period 2016 - 2019.
\end{abstract}

Keywords: DER, PER, EPS, stock prices.

\section{INTRODUCTION}

The rapid development of the Digital world led to economic competition. New entrepreneurs offer innovations that make it easier to carry out activities such as online motorcycle taxis, travel and e-commerce that enliven the digital economy in Indonesia. The business economy is currently entering an era of VUCA short for volatility, uncertainty, complexity and ambiguity. The Vuca era describes complex economic circumstances, rapid turmoil of change and obscurity. The fast-moving tide of change has made it difficult for businesspeople to anticipate what will happen next. The company is faced by unknown business challenges, business uncertainties, complex problems, difficulty making decisions. Companies should focus on efficiency to achieve performance goals. Leaders must have a long-term vision but can be adapted in the short term.

The challenges faced by business entrepreneurs in the VUCA era include market uncertainty, digital disruption, more automated processes, product optimization and improved life expectancy, Business and education must have strategies to face the VUCA era. Strategies for dealing with VUCA include continuous learning, adapting to existing circumstances, strategic thinking skills and daring to take risks.

The stock market is the market where the stock trades and where the company issues its shares. The stock market in Indonesia is known as the Indonesia Stock Exchange. The stock market shows the economic condition of a country. In developed countries, many companies are listed on the stock exchange. To see the economic condition of a country can be seen from the stock transactions in the country's stock market.

A share price is a price formed by demand and stock offerings in the capital market. The stock market price is determined by the capital market participants who trade stocks. A high share price will encourage investors to sell their shares. The high share price is formed due to the high demand for the company's shares in the capital market because the company performs well and has the potential to improve the quality of the company. The low share price is due to the lack of demand for the company's shares due to the company's poor performance and large business risks. The share price is used by investors to invest in the capital market in the form of purchasing ownership of the company. There are three types of value in the stock price valuation, namely book value, market value and intrinsic value [1]. A book value is a value calculated based on the publisher's bookkeeping, the market value is the value of the stock in the market, and the intrinsic value is the true value of the stock.

Based on the Indonesia Stock Exchange, companies engaged in the food and beverage sector in Indonesia recorded good growth until the end of 2019. PT Sariguna Primatirta Tbk (CLEO) recorded an 
increase in revenue and net profit during 2019. CLEO's revenue increased $30.64 \%$ from $\mathrm{Rp} 593.76$ billion to $\mathrm{Rp}$ 775.69 billion, while net profit doubled from last year to Rp 94.02 billion. PT Mayor Indah Tbk (MYOR) with net sales of $3.52 \%$ from $\mathrm{Rp} 17.35$ trillion to $\mathrm{Rp}$ 17.96 trillion. Sales to the domestic market as a major contributor amounted to Rp 9.91 trillion or $55.19 \%$ then export sales of Rp 9.06 trillion while returns amounted to Rp 9.43 billion. PT Nippon Indosari Corpindo Tbk (ROTI) recorded net sales of $24.05 \%$ from $\mathrm{Rp} 1.98$ trillion to $\mathrm{Rp} 2.46$ trillion. In addition, current period profit increased $151.93 \%$ from $\mathrm{Rp} 70.2$ billion to $\mathrm{Rp}$ 176.85 billion.

The study used indicators such as DER, PER, EPS and stock prices. DER is a ratio that demonstrates a company's ability to meet its obligations using equity. DER is a measure of the debt-to-debt ratio shared by the company's equity. DER is used to measure the health of the company. DER is often used as an indicator for making investment decisions. The high der indicates that the income level of the company to pay the company's debt is classified as low. Meanwhile, the low DER indicates that the level of profit earned by the company is very low.

PER is a ratio that compares the share price with earnings per share. Per is a number used as a fundamental analysis of the company's finances. PER is used to predict stock price developments. PER is derived from the divided share price of Earnings Per Share (EPS). The higher PER shows that the higher the market's view of the future of the economy. The lower PER suggests that markets are increasingly pessimistic about the future of the economy.

.EPS is a ratio that compares net income with the number of shares outstanding. According to [2] the EPS ratio is the ratio used to indicate the amount of money generated from each common share. EPS shows the amount of net income that is ready to be distributed to shareholders. The higher the EPS value means the greater the profit distributed to shareholders. EPS is a ratio that indicates the amount of income or income earned from each share. EPS is the first important component in analyzing a company. EPS information shows how much net profit is shared with all shareholders of the company. One indicator of the company's performance success is EPS. High EPS indicates that the better the company's performance, but there is no guarantee the share price will increase.

Previous research examining the influence of DER on the share price [3] states that partially variable DER has a significant effect on the share price. The results of research [4] state that DER has a significant effect on the share price. Previous researchers who conducted research on the effect of per on the share price [5] concluded in his study that per had a significant effect on the share price. The results of research conducted by [6] state that per variables have a positive and significant effect on the share price. Previous research examining the influence of EPS on the share price [5] concluded in his research that EPS had a significant effect on the share price. Research conducted by [7] states that variable EPS has a positive effect on the share price.

Based on the results of some of the above studies, the authors formulated problems in this study among others (1) is the significant influence between der, PER and EPS variables simultaneously on the share prices of food and beverage companies on the Indonesia Stock Exchange. (2) Is there a significant influence between DER, PER and EPS variables partially on the share prices of food and beverage companies on the Indonesia Stock Exchange. This research aims to analyze the influence of DER, PER and EPS on the Share Price of Food and Beverage Companies on the Indonesia Stock Exchange.

\section{LITERATURE REVIEW}

\subsection{Definition of DER}

One of the measuring tools for calculating leverage ratios by using DER. Debt To Equity Ratio is the ratio used to assess debt to equity [8]. This ratio is sought by comparing all debt, including current debt, with total equity. This ratio is used to determine the amount of funds given by borrowers (creditors) and owners of companies. In other words, this ratio is used to determine each rupiah of its own capital used as collateral for debt [8]. The value of the company will decrease if the company uses more debt than its own capital according to [9]. It can be concluded that DER shows the amount of each rupiah of the company's own capital used as debt collateral. Higher DER indicates that the funds taken from outside are getting bigger. Formula for calculating DER according to [10].

\section{Debt to Equity Ratio $=\underline{\text { Total Liabilities }}$ Total Equity}

\subsection{Definition of PER}

According to [1] PER is a ratio that shows the price of every one rupiah that investors must pay to get a company income of one rupiah. According to [11] companies that are expected to grow with a high growth rate (meaning have good prospects), usually have a high PER. Conversely, companies that are expected to have low growth will also have a low PER. Per describes the market appreciation of the company's ability to generate profit [12]. PER shows the ratio of share price to earnings. PER shows how much investors rate a stock's price against multiples of earnings. A high PER 
indicates that investors are willing to pay at a premium share price or a price above the market price [13]. Calculation formula PER by [1].

\section{PER = Share Price \\ Earning Per Share}

\subsection{Definition of EPS}

Comparison between the amount of income (in this case the net income ready to be distributed to shareholders) and the number of shares of the company to be acquired the Earning Per Share (EPS) component according to [1]. For investors, EPS information is considered the most basic and useful information because it can describe the company's future earnings prospects according to [1]. EPS is a ratio that indicates the share share of the yield. The Company may provide a high level of profit to shareholders indicated by high EPS. In contrast, lower EPS provides lower returns to shareholders. The increase in EPS will encourage investors to increase the amount of capital invested in the company, resulting in increased demand for the stock resulting in an increase in the share price according to him [12]. Formula calculates EPS According to [1].

\section{EPS $=$ Net Income}

\section{Number of shares outstanding}

\subsection{Definition of Share Price}

Shares are securities traded on the Indonesian equity market according to [1]. The share price is the price that occurs on the exchange at a certain time determined by the market participants according to [14]. The share price is distinguished into three nominal price, starting price and market price according to [15].

\subsection{Conceptual Framework}

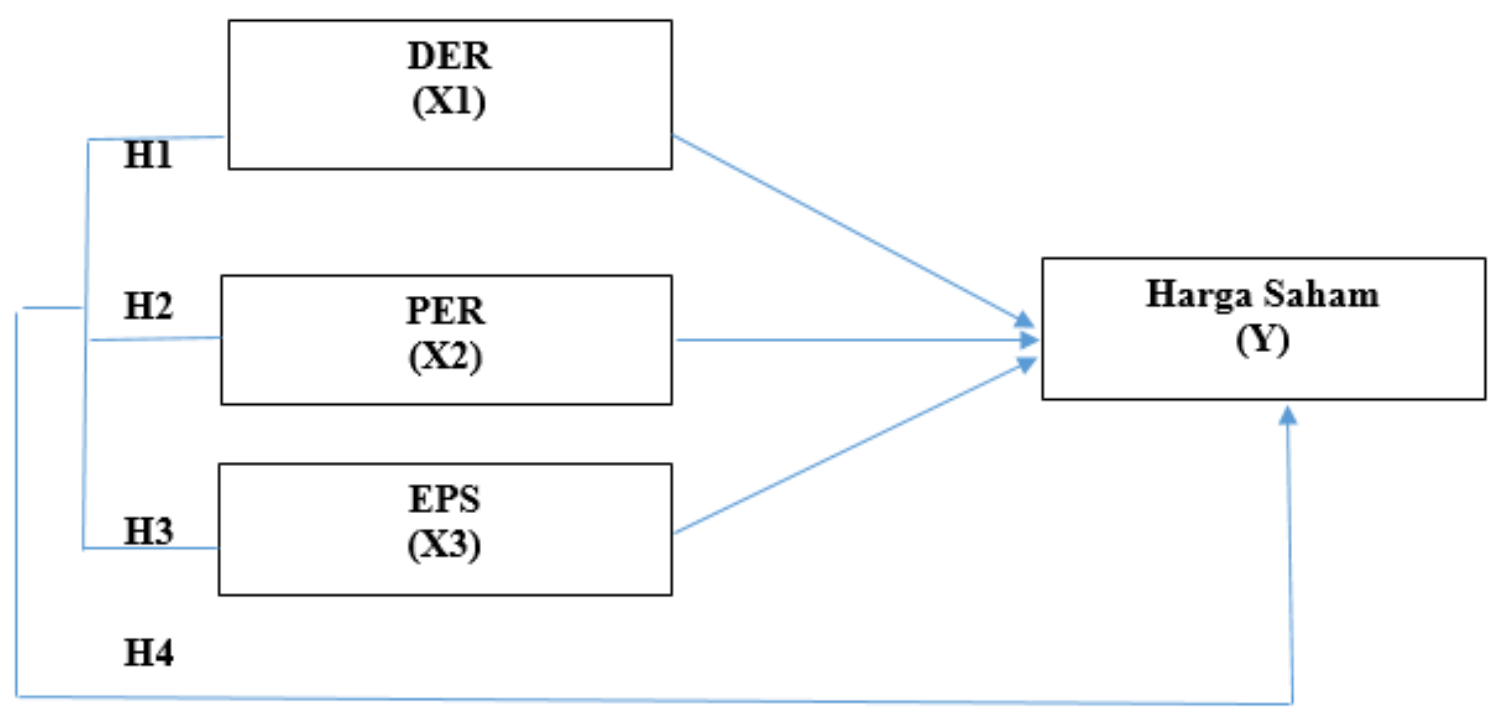

Figure 1. Conceptual Framework

Based on the conceptual framework above it can be described as follows:

1. Independent variables in this study are DER, PER and EPS.

2. The bound variable or bound variable in this study is the share price.

\subsection{Hypothesis}

H1: DER is suspected to have a significant impact on the share price of food and beverage companies in IDX for the period 2016-2019.

$\mathrm{H} 2$ : Per is suspected to have a significant impact on the share price of food and beverage companies in IDX for the period 2016-2019.
H3: EPS is suspected to have a significant impact on the share price of food and beverage companies in IDX for the period 2016-2019.

H4: DER, PER and EPS are suspected to have a significant impact on the share prices of food and beverage companies in IDX for the period 2016-2019.

\section{RESEARCH METHOD}

\subsection{Types Of Research}

This research is a descriptive quantitative research. The data collection method is literature study by looking at journals, books and literature studies related to the research topic. In this study 
the data were obtained by looking at the website of the Indonesia Stock Exchange. This study took samples from food and beverage industry companies listed on the Indonesia Stock Exchange for the period 2016-2019.

\subsection{Population and Sampling Techniques}

The company that sampled the research was a Food and Beverage industry company listed on the Indonesia Stock Exchange for the period 2016 2019. Sampling is done by purposive sampling method.

follows:

The sampling criteria in this study are as

1. Food and beverage industry companies recorded

consecutively in IDX for the period 2016-2019.

2. Food and beverage industry companies that have published full and consecutive financial statements from the period 2016 - 2019.

3. Food and beverage industry companies that have financial data according to der, per and EPS research variables.

4. Food and beverage industry companies that have logical data.

The number of food and beverage industry companies that meet the criteria of this research is as many as 15 companies. Food and beverage companies listed on the Indonesia Stock Exchange include PT Tiga Pilar Sejahtera Food, PT Tri Banyan Tirta, PT Wilmar Cahaya Indonesia, PT Mayora Indah, PT Prasidha Aneka Niaga, PT
Nippon Indosari Corpindo, PT Ultrajaya Milk Industry, PT Campina Industri Ice Cream, PT Garudafood Putra Putri Jaya, PT Sentra Food Indonesia, PT Wahana Interfood Nusantara, PT Era Mandiri Cemerlang, PT Diamond Food Indonesia, PT Pratma Abadi Nusa Industri, PT Sariguna Primatirta.

\subsection{Data Analysis Techniques}

The data analysis techniques in this study used SPSS version 24, including:

1. Classic Assumption Test

Normality Test, Heteroskedastity Test, Multicholineral Test and Autocorcord Test are used in classic assumption tests.

2. Multiple Linear Regression Analysis Test Consists of statistical test $\mathrm{t}$ and coefficient determination test.

\section{RESULTS AND DISCUSSION}

\subsection{Classic Assumption Test}

\subsection{Normality Test}

To find out if the data collected is normal distribution or not used normality test. The image below is a test result of normality using Kormogorov Smirnov.

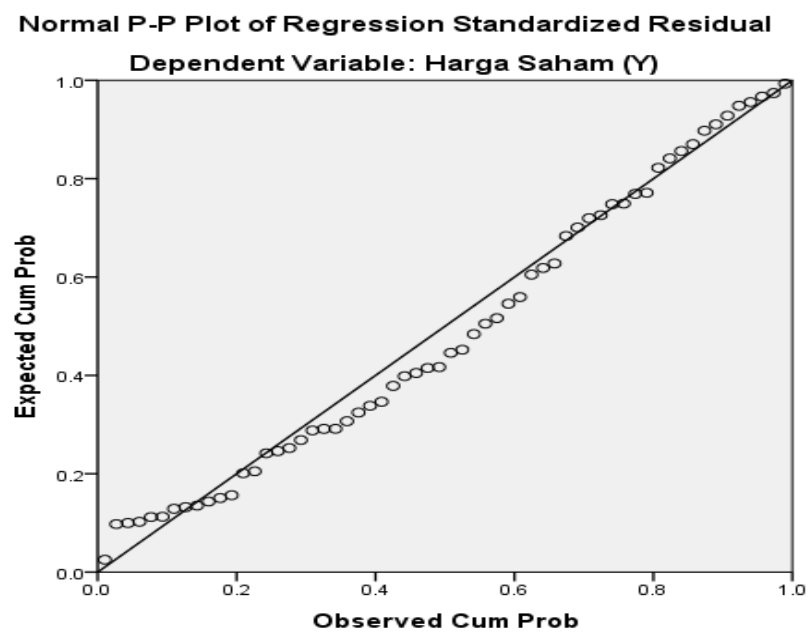

Figure 2. Probability Plot

Source: SPSS data, 2020

Based on Figure 2 above, it is known that the plotting data follows a normal line indicating that the data is distributed normally. Tests of normality using Kormogorov Smirnov can be concluded that the data is distributed normally.

\subsection{Multicolineity Test}

Multicholinearity tests are used to determine whether in regression models there is inter correlation or cholinearity between independent variables. The table below shows the results of the multicolinearity test. 
Table 1. The results of the multicolinearity test

\begin{tabular}{|c|c|c|c|c|c|c|c|c|}
\hline \multicolumn{9}{|c|}{ Coefficients $^{\mathrm{a}}$} \\
\hline \multirow[b]{2}{*}{ Model } & & \multicolumn{2}{|c|}{$\begin{array}{l}\text { Unstandardized } \\
\text { Coefficients }\end{array}$} & \multirow{2}{*}{$\begin{array}{l}\text { Standardized } \\
\text { Coefficients } \\
\text { Beta } \\
\end{array}$} & \multirow[b]{2}{*}{$\mathrm{T}$} & \multirow[b]{2}{*}{ Sig. } & \multicolumn{2}{|c|}{$\begin{array}{l}\text { Collinearity } \\
\text { Statistics }\end{array}$} \\
\hline & & B & Std. Error & & & & Tolerance & VIF \\
\hline \multirow[t]{4}{*}{1} & (Constant) & -7709.211 & 1293.857 & & -5.958 & .000 & & \\
\hline & DR (X1) & 873.145 & 579.335 & .181 & 1.507 & .137 & .448 & 2.230 \\
\hline & PER (X2) & 304.028 & 68.255 & .498 & 4.454 & .000 & .518 & 1.931 \\
\hline & EPS (X3) & 443.751 & 95.190 & .427 & 4.662 & .000 & .771 & 1.298 \\
\hline
\end{tabular}

a. Dependent Variable: Harga Saham (Y)

\section{Source: SPSS data, 2020}

Based on table 1 it appears that each variable has a VIF value of less than 10 , where dr obtains a VIF value of 2,230, PER 1,931 and EPS of 1,298. As for tolerance values for all independent variables there is no tolerance value smaller than 0.10 , where $\mathrm{DR}$ is obtained a tolerance value of 0.448 , PER 0.518 and EPS of 0.771 . Thus, it can be concluded that the data does not experience symptoms of multicholinearity because it has a tolerance value $>0.10$ and a VIF value of $<10$.

\subsection{Heteroskedastisity Test}

Heteroskedastisity tests are used to see if there are residual inequalities for all observations on linear regression models. Testing using heteroskedastisity test can be seen in the image below.

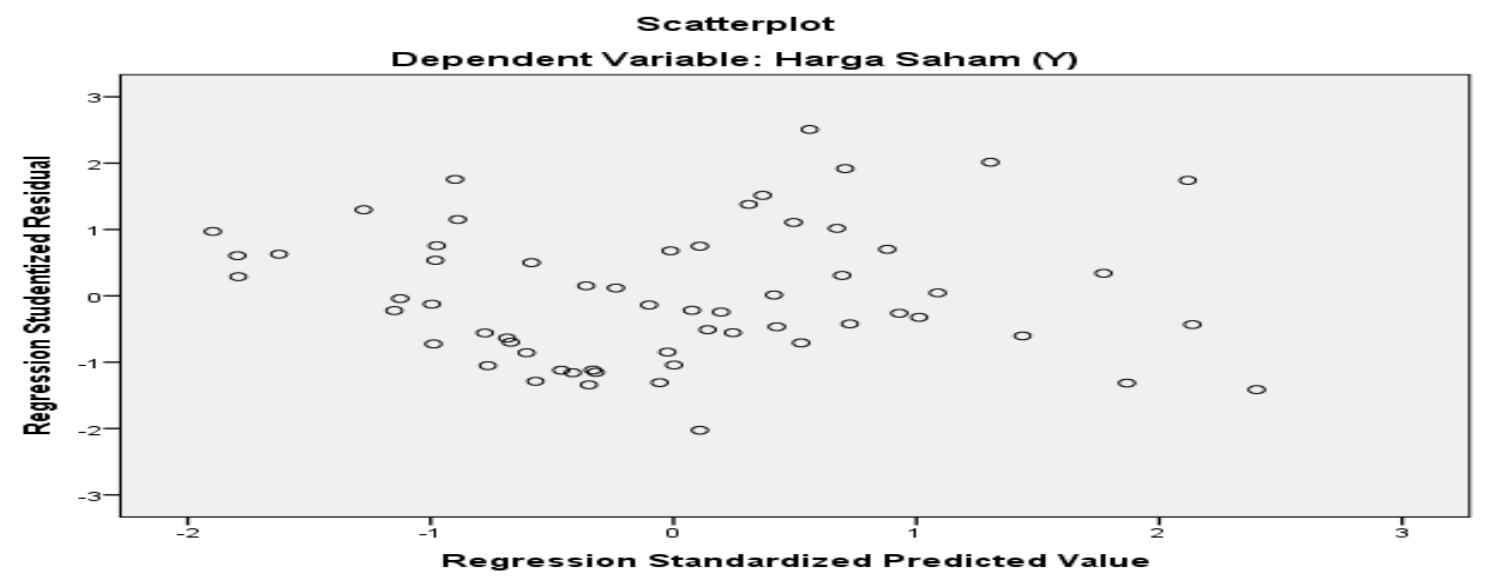

Figure 3. Scatterplot

\section{Source: SPSS data, 2020}

Based on Figure 3 above it is noticeable that the point spreads above the number 0 , the point not only gathers above and below, the point does not form a wavy, widening or narrowing pattern and the spread of the data point is not patterned. Of these, there are no symptoms of heteroskedastisity in variable DR, PER, EPS and share prices.

\subsection{Auto Correlation Test}

Auto correlation tests are used to determine if there is a correlation between variables in the prediction model and time changes. Test results with auto correlation test can be seen in the table below. 
Table 2. Autocorrelation Test

\begin{tabular}{|c|c|c|c|c|c|}
\hline Model & $\mathrm{R}$ & R Square & $\begin{array}{l}\text { Adjusted } \quad \mathrm{R} \\
\text { Square } \\
\end{array}$ & $\begin{array}{l}\text { Std. Error of the } \\
\text { Estimate }\end{array}$ & Durbin-Watson \\
\hline 1 & $.798^{a}$ & 637 & .618 & 2015.292 & 1.151 \\
\hline
\end{tabular}

Based on table 2 it appears that durbin watson value is 1,151 which in this test obtained results $\mathrm{dL}=$ 1.2437 and $\mathrm{dU}=1.6505$. So durbin watson's value lies in the $\mathrm{dU}$ range $<\mathrm{d}<4-\mathrm{dU}$ which is $1.6505<1.671$ $<2.3495$, this indicates that Durbin Watson is in the test area and can be concluded that the data has no symptoms of auto correlation.

\subsection{Multiple Linear Regression Analysis}

Multiple linear regression analysis is used to find out if there is an influence between free variables and bound variables expressed in the regression equation. Tests with multiple linear regression analysis can be found in the table below.

Table 3. Multiple Linear Regression

\begin{tabular}{|c|c|c|c|c|c|c|}
\hline \multirow{2}{*}{\multicolumn{2}{|c|}{ Model }} & \multicolumn{2}{|c|}{ Unstandardized Coefficients } & \multirow{3}{*}{$\begin{array}{l}\text { Standardized } \\
\text { Coefficients } \\
\text { Beta } \\
\end{array}$} & \multirow{3}{*}{$\begin{array}{l}\mathrm{t} \\
-5.958 \\
\end{array}$} & \multirow{3}{*}{$\begin{array}{l}\text { Sig. } \\
.000 \\
\end{array}$} \\
\hline & & \multirow{2}{*}{$\begin{array}{l}\text { B } \\
-7709.211\end{array}$} & \multirow{2}{*}{$\begin{array}{l}\text { Std. Error } \\
1293.857 \\
\end{array}$} & & & \\
\hline 1 & (Constant) & & & & & \\
\hline & DR (X1) & 873.145 & 579.335 & .181 & 1.507 & .137 \\
\hline & PER (X2) & 304.028 & 68.255 & .498 & 4.454 & .000 \\
\hline & EPS (X3) & 443.751 & 95.190 & .427 & 4.662 & .000 \\
\hline
\end{tabular}

Source: SPSS data, 2020

\section{$\mathrm{Y}=-7709,211+873,145 \mathrm{DR}+$ 304,028PER + 443,751EPS + e}

The above equations can be interpreted as follows:

1. $\alpha=-7709,211$, meaning that if all independent variables are zero, then the share price variable (Y) is worth $-7709,211$.

2. $\beta 1=873.145$, meaning that if DR rises $1 \%$, then the variable share price $(\mathrm{Y})$ will rise by 873,145 assuming other variables are considered constant. The coefficient is relatively positive which means there is a positive relationship between DR and the share price.

3. $\beta 2=304,028$, meaning that if PER rises $1 \%$ then the variable share price will drop by 304,028 assuming other variables are considered constant. A positively marked coefficient means there is a positive relationship between PER and the share price.

4. $\beta 3=443,751$, meaning that if EPS rises $1 \%$ then the variable share price will rise by 443,751 assuming other variables are considered constant. The coefficient is considered positive meaning there is a positive relationship between EPS and the share price.

\subsection{Coefficient of Determination (R2)}

The determination coefficient (R2) is used to determine how much the contribution of independent variables contributes simultaneously to dependent variables. The results of the determination coefficient (R2) test can be seen in the table below.

Table 4. Determination Coefficient

\begin{tabular}{ll|l|l|l}
\hline Odel & R & R Square & Adjusted R Square & $\begin{array}{l}\text { Std. Error of the } \\
\text { Estimate }\end{array}$ \\
\hline 1 & $.832^{\mathrm{a}}$ & .693 & .673 & 2024.694 \\
\hline
\end{tabular}

Source : SPSS data, 2020

Based on table 4 it appears that the Adjusted R2 value is 0.693 . This data shows that variable share prices are affected by $69.3 \%$ by variables (DR), (PER) and (EPS). Meanwhile, the remaining 30.7\% was influenced by other variables outside the variables in the study.

\subsection{Hypothesis Testing}

\subsubsection{T Test (Partial)}

The $t$ test is used to determine the influence of each individual independent variable on dependent variables. 
The test results of the $\mathrm{T}$ test can be seen in the table

below.

Table 5. Partial Test (t)

\begin{tabular}{|c|c|c|c|c|c|c|}
\hline & \multirow[b]{2}{*}{ Model } & \multicolumn{2}{|c|}{ Unstandardized Coefficients } & \multirow{2}{*}{$\begin{array}{l}\text { Standardized } \\
\text { Coefficients } \\
\text { Beta }\end{array}$} & \multirow[b]{2}{*}{$\mathrm{t}$} & \multirow[b]{2}{*}{ Sig. } \\
\hline & & $\mathrm{B}$ & Std. Error & & & \\
\hline \multirow[t]{4}{*}{1} & (Constant) & -7709.211 & 1293.857 & & -5.958 & .000 \\
\hline & DR (X1) & 873.145 & 579.335 & .181 & 1.507 & .137 \\
\hline & PER (X2) & 304.028 & 68.255 & .498 & 4.454 & .000 \\
\hline & EPS (X3) & 443.751 & 95.190 & .427 & 4.662 & .000 \\
\hline
\end{tabular}

Source: SPSS data, 2020

Based on table 5 above obtained t test statistics as follows:

1. (DR) has a t-count of 1,507 with a significance value of 0.137. Because the sig t value is 0.137> alpha 0.05 . So it can be concluded that partially variable DER has no significant effect on the share price, meaning the share price means Ho accepted Ha was rejected.

2. (PER) has a $t$ count of 4,454 with a significance value of 0.000 . Because the sig $\mathrm{t}$ value is 0.000 $<0.05$. So it can be concluded that partially variable PER had a significant effect on the share price, in other words Ho rejected, Ha accepted.
3. (EPS) has a $t$ count of 4,662 with a significance value of 0.000 . Because the sig $t$ value is 0.000 $<0.05$. So it can be concluded that partially variable EPS had a significant effect on the share price, in other words Ho rejected, Ha accepted.

\subsubsection{F Test (Simultaneous)}

Test $F$ is used to determine the effect of independent variables together on dependent variables. The table below shows the test results of $\mathrm{F}$.

Table 6. Simultaneous Test (F)

\begin{tabular}{|c|c|c|c|c|c|c|}
\hline \multicolumn{7}{|c|}{ ANOVA $^{\mathrm{a}}$} \\
\hline Model & & Sum of Squares & Df & Mean Square & $\mathrm{F}$ & Sig. \\
\hline \multirow[t]{3}{*}{1} & Regression & 399566450.100 & 3 & 133188816.700 & 32.794 & $.000^{\mathrm{b}}$ \\
\hline & Residual & 227438614.600 & 56 & 4061403.833 & & \\
\hline & Total & 627005064.700 & 59 & & & \\
\hline \multicolumn{7}{|c|}{ a. Dependent Variable: Harga Saham (Y) } \\
\hline b. Pred & ors: (Consta & EPS (X3), PER & , DR & & & \\
\hline
\end{tabular}

Based on table 6 shows simultaneous test results between variables DR (X1), PER (X2) and EPS (X3) against Share Price (Y). Table 6 shows the value of significance (Sig.) 0.000. Because of Sig. $0.000<0.05$ probability, so it can be concluded $\mathrm{H} 4$ is accepted, meaning variables DR (X1), PER (X2) and EPS (X3) simultaneously affect the Variable Share Price (Y).

\section{DISCUSSION}

\subsection{Effect of DER on Stock Prices}

Based on the hypothetical test results using SPSS 24 the value of DER variable significance of 0.137 to $0.137>0.05$ means the DER variable has no significant effect on the share price. The above testing shows that H1 was rejected. High DER indicates that the company's debt is also high, indicating that the company relies heavily on equity financing to pay down high debt. According to [16] this will cause investors to tend to avoid the company's shares, the lower the market demand then the lower the share price.

The results of this study are in line with research conducted by [17] which stated that DER variables negatively and insignificant to the share price. Research conducted by [18] states that partial der variables to the share price have no effect. The results of this study are not in line with research conducted by [19] which stated that DER has a negative relationship and has a significant effect on the share price. Sudaryanto's research states that partially der variables have a negative and significant effect on the share price. Research conducted by [20] states that partially variable DER has no effect on the share price. 


\subsection{The Effect of PER on Stock Prices}

Based on hypothetical test results using SPSS 24, the value of PER variable significance is 0.000 to $0.000>0.05$ meaning there is a positive and significant influence between PER variables on the share price. The above testing shows that $\mathrm{H} 2$ is accepted. A higher PER caused investor confidence in the company to increase. This can increase investor interest in investing in the company so that the company's share price will rise.

The results of this study are in line with research conducted by [21] which stated that per variables affect the share price. [22] stated that PER had a positive effect on the share price. Research that disagrees with opinion [23] states that partially per variables have no effect on stock returns.

\subsection{The Effect of EPS on Stock Prices}

Based on hypothetical test results using SPSS 24 obtained an EPS variable value of 0.000 , up to $0.000>0.05$ which means there is a positive and significant influence between EPS variables on the share price. The above testing shows that $\mathrm{H} 3$ is accepted. The higher the EPS indicates that the company has managed to increase the level of investor prosperity. This causes investors to willingly increase the amount of capital that will be invested in the company's shares. The higher the demand for the company's shares, the higher the share price.

The results of this study are in line with research conducted by [24] which stated that variable EPS has a significant effect on the share price simultaneously and partially. Research conducted by [20] states that partially variable EPS has a positive effect on the share price. [18] stated that partially variable EPS against share price variables had a positive effect. [22] said EPS had a positive effect on the share price. [25] stated that partial EPS had a positive and significant effect on the share price. The research was conducted by [23] states that partially variable EPS has no effect on stock returns. Different opinions from research [26] reveal that EPS has no effect on the share price. The Opinion fo [6] states there is a negative and insignificant relationship between variable EPS to the share price. The opinion of [27] states that there is a positive but insignificant relationship between variable EPS to the share price.

\subsection{The Effect of DER, PER and EPS on Stock Prices}

Based on the results of simultaneous hypothesis testing using SPSS 24 obtained a value of DR, PER and EPS significance of 0.000 , so $0.000>0.05$ means there is a positive and significant influence between DR, PER and EPS variables on the share price. The above testing shows that $\mathrm{H} 4$ is accepted. This means DR, PER and EPS can jointly increase the share price.

The results of this study are in line with research conducted by [5] which revealed that DR, PER, EPS and Size simultaneously have a significant effect on the share price. The research was conducted by [23] discloses that PER and EPS simultaneously have a significant effect on stock returns. [22] stated that PER and EPS simultaneously had a significant effect on the share price.

\section{CONCLUSION}

The conclusions obtained based on the above discussions are DER has no significant and positive effect on the share price of food and beverage industry companies listed on the Indonesia Stock Exchange for the period 2016 - 2019. PER and EPS has a significant and positive effect on the share price of food and beverage industry companies listed on the Indonesia Stock Exchange for the period 2016 - 2019. Also, DR PER and EPS simultaneously have a significant and positive effect on the share prices of food and beverage industry companies listed on the Indonesia Stock Exchange for the period 2016 - 2019.

This study only discusses the influence of DER, PER and EPS on the share price, for researchers are further advised to add research variables and increase the research period so that more accurate research results are obtained.

\section{REFERENCES}

[1] Tandelilin, Eduardus. Portfolios and Investment: Theory and Applications. Canisius. Yogyakarta. 2010

[2] Hanum, Zulia, "Effect of Return On Assets (ROA), Return On Equity (ROE) and Earning Per Share (EPS) on Stock Prices in Automotive Companies Listed on the Indonesia Stock Exchange 2008-2011 Period', Management \& Business Journal, Vol.8, No.2, pp.1693-7619, April. 2009 DOI: http://jurnal.umsu.ac.id/index.php/kumpulandosen /article/view/301/pdf_22

[3] Munira M, Merawati EE \& Astuti SB, "The Effect of ROE and DER on Stock Prices of Paper Companies on the Indonesia Stock Exchange", Journal OF Applied Business and Economics, Vol.4, No.3, pp. 191-205, March. 2018 DOI https://journal.lppmunindra.ac.id/index.php/JABE/ article/view/2478/1869

[4] Alfiah N \& Diyani LA. "The Effect of ROE and DER on Stock Prices in the Retail Trading Sector", Journal of Applied Business, Vol. 1, No.2, Pp. 47-54,Dec.2017 DOI: https://journal.ubaya.ac.id/index.php/JIBT/article/ view/794/619

[5] Viandita TO, Suhadak \& Husaini A, "The Effect of Debt Ratio (DR), Price To Earning Ratio 
(PER), Earning Per Share (EPS) and Size on Share Prices (Studies on Industrial Companies Listed on the Indonesian Stock Exchange', Journal of Business Administration, Vol.1, No.2, pp. 113121, 2013 DOI : http://administrasibisnis.studentjournal.ub.ac.id/in dex.php/jab/article/view/47/1595

[6] Rahmadewi PW and Abundanti N, "Effect of EPS, PER, CS and ROE on Stock Prices on the Indonesia Stock Exchange', E-Journal of Management of Udayana University, Vol.7, No. 4, pp. 2106-2133, 2018 DOI : https://www.neliti.com/publications/254641/penga ruh-eps-per-cr-dan-roe-terhadap-harga-saham-dibursa-efek-indonesia

[7] Badruzaman J, "Effect of Earning Per Share on Stock Prices", Accounting journal, Vol. 12, No. 1, pp.102-110,2017

DOI: http://jurnal.unsil.ac.id/index.php/jak/article/view/ $298 / 210$

[8] Kasmir. Financial Statement Analysis. First Edition. Jakarta. : PT. Rajagrafindo Persada. 2014.

[9] Sudana, I Made. Corporate Financial Management Theory and Practice. Jakarta : Erlangga. 2011

[10] Fahmi, Irham. Introduction to Financial Management. Bandung : Alfabeta. 2014

[11] Hanafi, Mamduh M. Financial Management. Yogyakarta : BPFE. 2010.

[12] Darmaji, Tjiptono and Fakhrudddin, Capital Market in Indonesia. Third Edition. Jakarta : Four Salemba. 2012

[13] Jogiyanto. Portfolio Theory and Investment Analysis. Fifth Edition. Yogyakarta: BPFE. 2010.

[14] Hartono, Jogiyanto. Portfolio Theory and Investment Analysis. Ninth Edition. Yogyakarta : BPFE. 2013

[15] Sunnariyah. Capital Market Knowledge. Yogyakarta : UPP STIM YKPN. 2013

[16] Ratih D, Apriatni \& Saryadi, "The Effect of EPS, PER, DER and ROE on Share Prices in Mining Companies Listed on the Indonesia Stock Exchange (BEI) 2010-2012”, Diponegoro Journal of Social and Politic, pp.1-12, 2014 DOI: https://www.neliti.com/publications/103211/penga ruh-eps-per-der-roe-terhadap-harga-saham-padaperusahaan-sektor-pertambanga

[17] Sari, DI, "The Effect of CR and DER on Stock Prices of Automotive Companies', JADDewantara Accounting Research Journal, Vol. 4 No.1,pp.66-77, April. $2020 \quad$ DOI: https://ejournal.stiedewantara.ac.id/index.php/JAD /article/view/522/296

[18] Utami MR \& Darmawan A, "Effect of DER, ROA, ROE, EPS and MVA on Stock Prices on the Indonesian Sharia Stock Index', Journal of
Applied Of Applied Managerial Accounting, Vol.2, No.2, pp.206-218,Sept.2018 DOI: https://jurnal.polibatam.ac.id/index.php/JAMA/arti cle/view/910/571

[19] Nugraha RD \& Sudaryanto B, "Analysis of the Effect of DPR, DER, ROE and TATO on Stock Prices (Case Study of Basic Industry and Chemical Companies Listed on the Indonesia Stock Exchange", Diponegoro Journal of Management, Vol.5, No.4, pp. 1-12, 2016 DOI https://ejournal3.undip.ac.id/index.php/djom/articl e/view/17873/16946

[20] Alipudin A \& Oktaviani R. "Effect of EPS, ROE, ROA and DER on Stock Prices in Cement Sector Companies Listed on the IDX", JIAFE, Vol. 2, No.1,pp.1-22,2016 DOI: https://journal.unpak.ac.id/index.php/jiafe/article/v iew/521/431

[21] Beliani MMI \& Budiantara M, "The Effect of Price Earning Ratio and Price To Book Value on Stock Prices of Insurance Companies Listed on the Indonesia Stock Exchange in 2009-2012", JRAMB, Vol.1, No.1, pp. 77-86, May. 2015 DOI: https://ejurnal.mercubuanayogya.ac.id/index.php/akuntansi/article/view/12

[22] Aletheari IDM and Jati IK. "The Effect of Earning Per Share, Price Earning Ratio, and Book Value Per Share on Stock Prices", Udayana University Accounting E-Journal. Vol. 17, No.2, pp. 1254 1282,Nov.2016

DOI: https://ojs.unud.ac.id/index.php/Akuntansi/article/ view/21667/16032

[23] Sodikin S \& Wuldani N, "The Effect of Price Earning Ratio (PER) and Earning Per Share (EPS) on Stock Returns (Study at PT Unilever Indonesia Tbk)", Journal of Management Economics, Vol. 2 No.1,pp.18-25,May.2016 DOI: http://jurnal.unsil.ac.id/index.php/jem/article/view/ $\underline{309 / 221}$

[24] Cahyaningrum YW \& Antikasari TW, "The Effect of Earning Per Share, Price To Book Value, Return On Assets and Return On Equity Against Stock Prices in the Financial Sector", Journal of Economia" Vol.13, No.2, pp. 191-200, Oct. 2017 DOI:

https://journal.uny.ac.id/index.php/economia/articl e/view/13961/pdf

[25] Mahadewi \& Candraningrat,"The Effect of Return On Asset, Earning Per Share and Debt Ratio on Stock Prices at LQ-45 Index Companies in the Indonesia Stock Exchange" Management EJournal, Vol.3, No.12, pp. 3558-3577, 2014 DOI : https://ojs.unud.ac.id/index.php/Manajemen/article /view/9975/7912

[26] Khairani I, "The Effect of Earning Per Share (EPS) and Dividend Per Share on Share Prices of Mining Companies Listed on the Indonesia Stock 
Exchange (BEI) 2011-2013", Journal of Management and Finance, Vol.5, No.1, pp. 566572,May.2016 DOI: https://ejurnalunsam.id/index.php/jmk/article/view $175 / 48$

[27] Ginsu FFG, Saerang IS \& Roring F, "Effect of Earning Per Share (EPS) and Return On Equity
(ROE) on Stock Prices (Case Study in the Food and Beverage Industry Listed on the Indonesia Stock Exchange for the period 2013-2015", Journal of EMBA, Vol.5, No.2, pp. 1327-1336, June. $2017 \quad$ DOI: https://ejournal.unsrat.ac.id/index.php/emba/article /view/16162/15667 